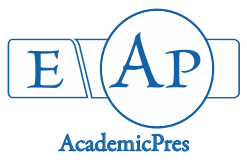

Borisade TV (2020)

Notulae Scientia Biologicae 12(4):929-939

DOI: $10.15835 / 12410587$

Research Article

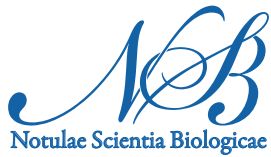

\title{
Lignin, cellulose and nutrient deposition in litters of Bambusa vulgaris stands in a regenerating forest in Ile-Ife, Nigeria
}

\author{
Tolulope V. BORISADE*
}

Obafemi A wolowo University, Faculty of Science, Department of Botany, Ile-Ife, BC220005

Nigeria; tolulopeborisade2017@gmail.com ("corresponding author)

\begin{abstract}
The lignin, cellulose and nutrient deposition of litters were assessed in four 0.06 ha plots of Bambusa vulgaris stands in a regenerating forest in Ile-Ife, Nigeria, 35 years after ground fire, with a view to providing information on these parameters which are generally lacking in the forest ecosystem. The collected litters were sorted into leaves and twigs, oven-dried at $70^{\circ} \mathrm{C}$ to a constant weight, ground and analysed for lignin, cellulose and nutrients. The total lignin and cellulose content in the litters showed significant $(\mathrm{p} \leq 0.05)$ monthly variation. There was no significant $(\mathrm{p} \geq 0.05)$ difference in the monthly nutrient deposition of $\mathrm{Na}, \mathrm{Mg}, \mathrm{K}, \mathrm{Fe}$, $\mathrm{N}, \mathrm{P}, \mathrm{Mn}, \mathrm{Zn}$ and $\mathrm{Cu}$, but there was significant difference in the monthly nutrient deposition of $\mathrm{C}$ and $\mathrm{Ca}$ through the litter fall fraction $(\mathrm{p} \leq 0.05)$ in the bamboo stands in the secondary rainforest. The depositions of $\mathrm{C}, \mathrm{N}, \mathrm{Ca}, \mathrm{Mg}$ and $\mathrm{Cu}$ were higher in the bamboo stands but lower in $\mathrm{Na}, \mathrm{Mn}$ and $\mathrm{Zn}$ deposition in 1990 and 2013 studies. The bamboo stands contributed significantly to the carbon sequestration, nutrient dynamics and regeneration status of the forest.
\end{abstract}

Keywords: cellulose; lignin; litters; nutrient deposition; seasons

\section{Introduction}

Bamboo is a naturally occurring composite material because it consists of cellulose fibers embedded in a lignin matrix which are aligned along the length of the bamboo providing maximum tensile flexural strength and rigidity (Uday et al., 2008). It is found growing abundantly in most tropical countries. In Nigeria, it is continuously harvested from forests and used mainly as timber due to these properties. Studies have shown that for thermochemical conversion of biomass to energy, high lignin content is desirable, though the extent of its effect is not well known (Cassida et al., 2005; Boateng et al., 2008) and bamboo possesses high content of lignin and cellulose making it very essential in the processing of biomass energy used in many industries worldwide. Bamboo, the 'green gold', has the potential to conserve natural forest ecosystems through timber substitution (Hunter and Junqui, 2002), mitigate global warming through carbon sequestration (Das and Chaturvedi, 2006), and substitute non-biodegradable and high energy-embodied materials such as plastics and metals with polymer composites (Okubo et al., 2004) and plays a vital role in the recruitment, regeneration and nutrient status of woody species in a regenerating secondary forest. In view of the need to reducing the alarming rate of forest degradation and deforestation to mitigating the adverse effects of global climate change, the use of bamboo as basic raw material in lieu of woody products has become very imperative. The production of litter 
plays a fundamental role in the biogeochemical cycle of organic matter and mineral nutrients, thus becoming a key component in the functioning and stability of forest ecosystems. Studies have reported the litters of bamboo stand to have higher nutrient content of $\mathrm{C}, \mathrm{N}, \mathrm{P}$ compared to most trees and shrubs species in natural forests (Anonymous, 1997; Zhou 2005; Borisade and Odiwe, 2018).

Nutrient accumulation and dynamics in bamboo plantations have been studied extensively (Shanmughavel et al., 2001), but natural bamboo forests and bamboo stands in tropical forests of Africa especially in Nigeria have not been well studied (Borisade and Odiwe, 2018). Studies relating to lignin, cellulose and nutrient deposition in the litters of bamboo stands in natural forests are generally lacking, especially in Western part of Nigeria. This study therefore, assessed the mean monthly nutrients deposition, lignin and cellulose content in the litters of bamboo stands in a regenerating rainforest with the aim of providing information on this subject matter which are generally lacking in the African tropical forest ecosystems. The results from this study were compared with previous studies on nutrients deposited through litter fall for woody species in the same secondary forests with the aim of assessing the role played by bamboo to influencing the carbon sequestration, nutrient dynamics and regeneration status of the forest.

\section{Materials and Methods}

\section{Studyarea}

The study was carried out in the secondary rainforest within the Biological Garden of Obafemi Awolowo University, Ile-Ife, Nigeria. Ile-Ife lies within latitudes $7^{\circ} 30^{\prime} \mathrm{N}$ to $7^{\circ} 35^{\prime} \mathrm{N}$ and longitudes $4^{\circ} 30^{\prime}$ to $4^{\circ} 35^{\prime} \mathrm{E}$. The coordinates of the study areas are: Latitude $7^{\circ} 31.417^{\prime}$ to $7^{\circ} 31.422^{\prime} \mathrm{N}$, and Longitude $4^{\circ} 31.442^{\prime}$ to $4^{\circ} 31.455^{\prime} \mathrm{E}$. The details of the climate, soil and the vegetation of the study area are described in Borisade and Odiwe (2018).

\section{Data collection}

Four study plots were established within the secondary rainforest, each sampling plot of size; $25 \mathrm{~m} \times 25$ $m$ was marked out using measuring tape and demarcated with narrow cut-lines. Ten litters trap each, were randomly positioned in the four established plots of $B$. vulgaris stands and located within the secondary rainforest. Samples were collected fortnightly for a period of a year (June 2014-May 2015).

\section{Chemical analysis}

Ground litter fall and litter standing crop samples, were digested using mixed acid (nitric-perchloricacid) digestion procedure of Allen et al. (1974). $0.2 \mathrm{~g}$ sub-sample of each ground samples was digested in 7.0 $\mathrm{mL}$ of the digestion mixture. The digest was analysed for calcium and magnesium using Atomic Absorption Spectrometer (Alpha Model 4). Potassium and sodium were determined using flame photometer (Model Corning 400). Total carbon and nitrogen were determined based on the principle of "Dumas method using elemental analyzer (CHNS) (Perkin Elmer 240). Lignin and cellulose were determined using the procedures of chemical analysis described by Van Soest and Robertson (1985) and Goering and Van soest (1970) respectively. Phosphorus, Iron, Manganese and Copper of the ground litter samples was determined at the International Institute of Tropical Agriculture (IITA), Ibadan, according to the method of Tel and Rao (1982).

\section{Estimation of lignin, cellulose and mean monthly nutrients deposition}

The monthly weight of litter fall was determined by adding the oven-dry weight of the individual traps of all leaf fractions, each month and this was similarly done for the litter standing crop samples. The lignin, cellulose and mean monthly nutrient deposition was calculated as the product of the monthly litter production of each component (leaf and twig) and mean monthly nutrient concentrations of the corresponding 
components (Borisade and Odiwe, 2018). While, adding over the months to obtain the accumulated values which was used to obtaining the annual nutrient deposition used for comparison with areas where the stands are not situated within the secondary forests that is previous studies on nutrient deposition in litters of woody species (Source of 1990 data is from Muoghalu et al., 1993 and 2013 data is from Afolabi, 2014).

\section{Statistical analysis}

Analysis of variance (ANOVA) was used to test for significant monthly nutrient deposition in the litter fall and litter standing crop; lignin and cellulose content. Descriptive statistics: Mean \pm Standard error and bar chart were employed in presenting results obtained from this study. The test was performed using System Analysis Software version 8.0 (SAS, 1999).

\section{Results}

\section{Lignin content in litters of the bamboo stands}

The total lignin content in the bamboo litters showed significant monthly variation $(p \leq 0.05)$. The monthly variation in the lignin content indicated that it was at its peak in the month of December and least in April (Figure 1a) but there was no significant difference ( $p>0.05)$ between the leaf and twig fractions across the months studied. In the litter standing crop, there was a significant $(\mathrm{p}<0.05)$ difference in the lignin content between the litter components and across the peak of seasons (Figure 1b). The lignin content of the leaf showed no significant differences across peak of season but the twig component was higher in the rainy than dry season. The lignin content in the peak of rainy season was higher than in the peak of dry season.

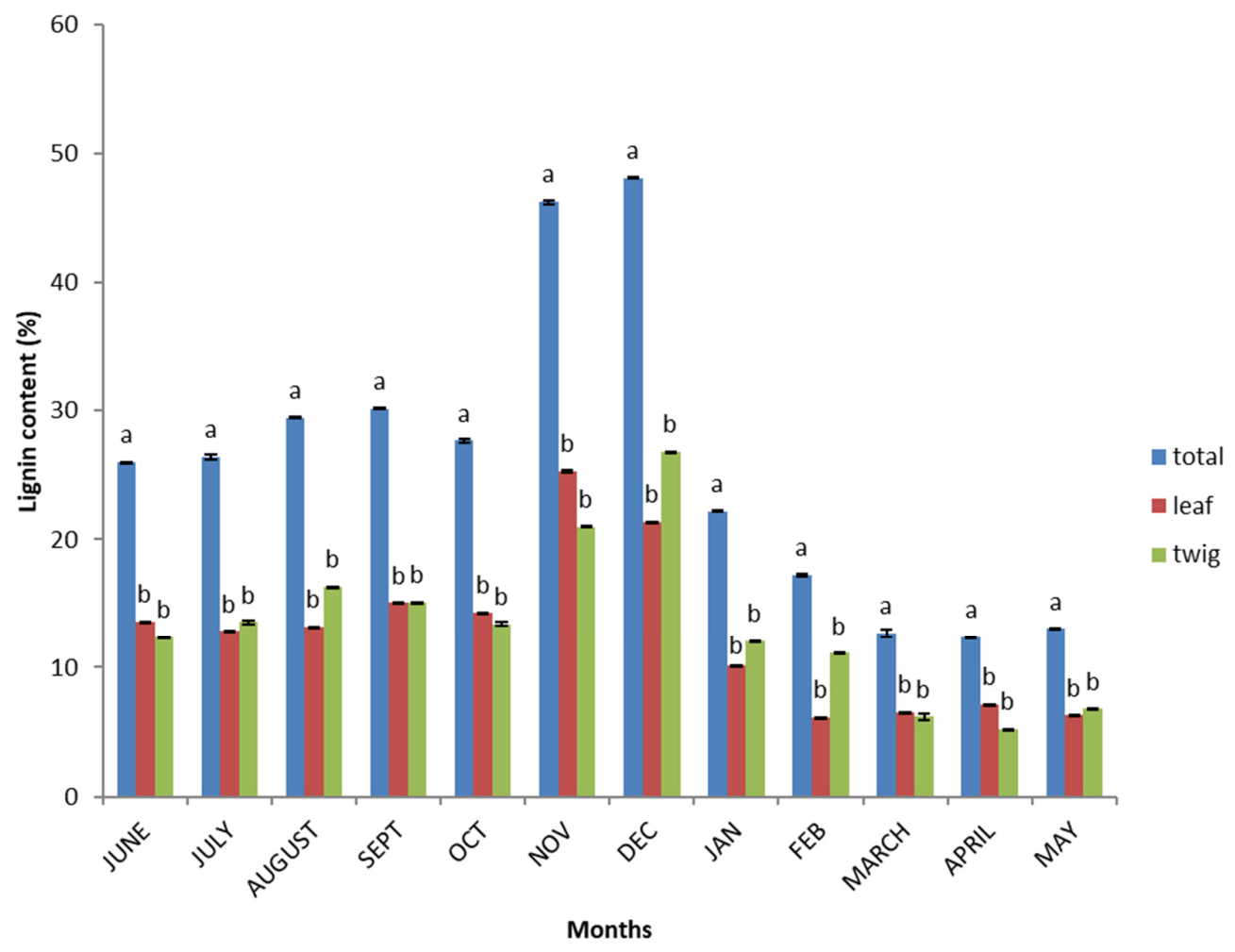

Figure 1a. Monthly lignin content in the litter fall of bamboo stands in a regenerating forest, Ile-Ife *Vertical bars of the same alphabet in a month are not significantly $(\mathrm{p}>0.05)$ different using Duncan Multiple Range Test (DMRT). 


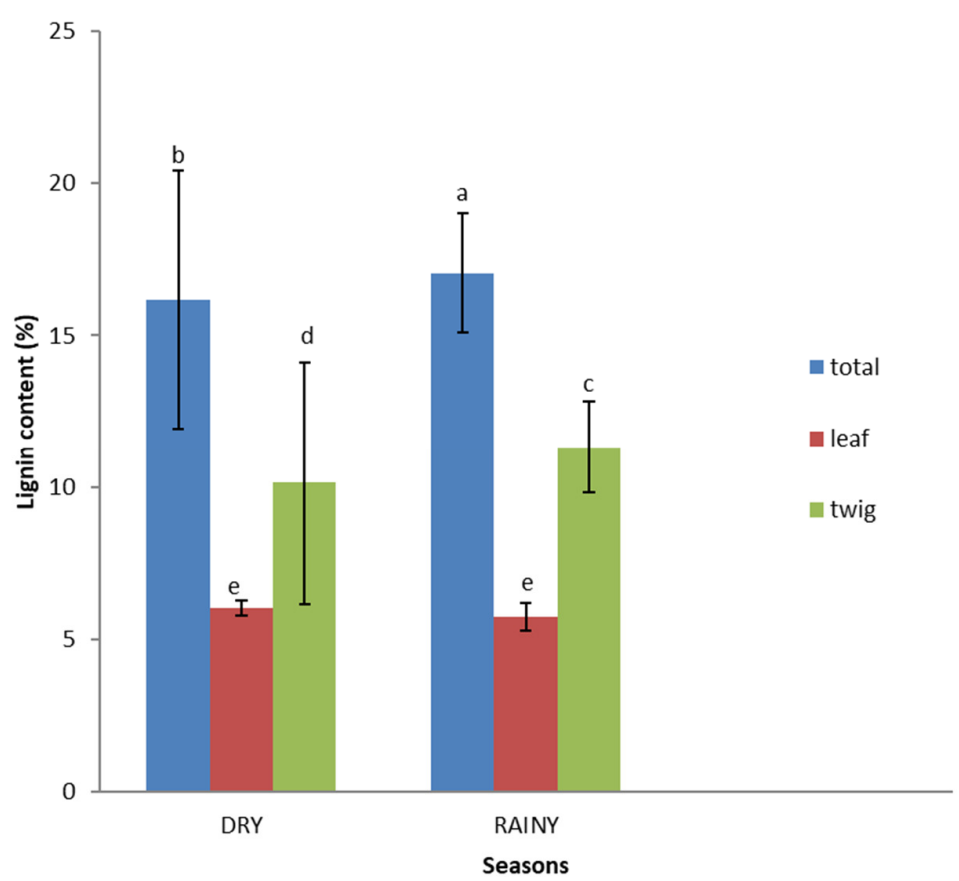

Figure 1b. Lignin Content in the litter standing crop of bamboo stands at the peak of seasons in a regenerating forest, Ile-Ife

${ }^{*}$ Vertical bars of the same alphabet in a month are not significantly $(\mathrm{p}>0.05)$ different using Duncan Multiple Range Test (DMRT)

\section{Cellulose content in litter fall and standing crop of litters in the bamboo stands}

The total cellulose content in the litter fall of bamboo stands showed monthly variations (Figure 2a). There was no significant difference $(p>0.05)$ between the leaf and twig fractions, similar observation was made in the litter standing crop components across the peak of seasons (Figure 2b).

\section{Mean monthly nutrients deposition in litters of the bamboo stands}

The mean monthly nutrient deposition (Kg/ha) of C, N, P, K, Ca and Mg ranged from 94.37-700.11, 5.98-26.79, 0.014-0.046, 1.56-6.98, 6.11-28.98 and 2.11-12.3 respectively (Figure 3a-c). There was no significant ( $\mathrm{p} \geq 0.05$ ) difference in the monthly nutrient deposition of $\mathrm{Na}, \mathrm{Mg}, \mathrm{K}, \mathrm{Fe}, \mathrm{N}, \mathrm{P}, \mathrm{Mn}, \mathrm{Zn}$ and $\mathrm{Cu}$ in the bamboo stands in the secondary rainforest through litter fall fractions (Monthly nutrient deposition via litter fall in the bamboo stands in a Regenerating rainforest, Ile-Ife). There was significant difference in the monthly nutrient deposition of $\mathrm{C}$ and $\mathrm{Ca}$ through the litter fall fraction $(\mathrm{p} \leq 0.05)$ (Monthly nutrient deposition via litter fall in the bamboo stands in a regenerating rainforest, Ile-Ife). The highest deposition of Ca occurred in January and March in the leaf and twig litter respectively while $\mathrm{C}$ deposited higher in leaf than twig throughout the months studied notably in December and January (Monthly nutrient deposition via litter fall in the bamboo stands in a regenerating rainforest, Ile-Ife). The C, N, P and $\mathrm{K}$ deposition in the total litter standing crop at the peak of the two seasons was $37.38,16.95,0.01$ and $8.95 \mathrm{Kg} \mathrm{ha}^{-1}$ respectively (Monthly nutrient deposition via litter fall in the bamboo stands in a regenerating rainforest, Ile-Ife). There was significant difference in the nutrient's deposition through the litter fall fraction across peak of seasons with the dry higher than rainy season $(\mathrm{p} \leq 0.05)$ (Table 1$)$. 


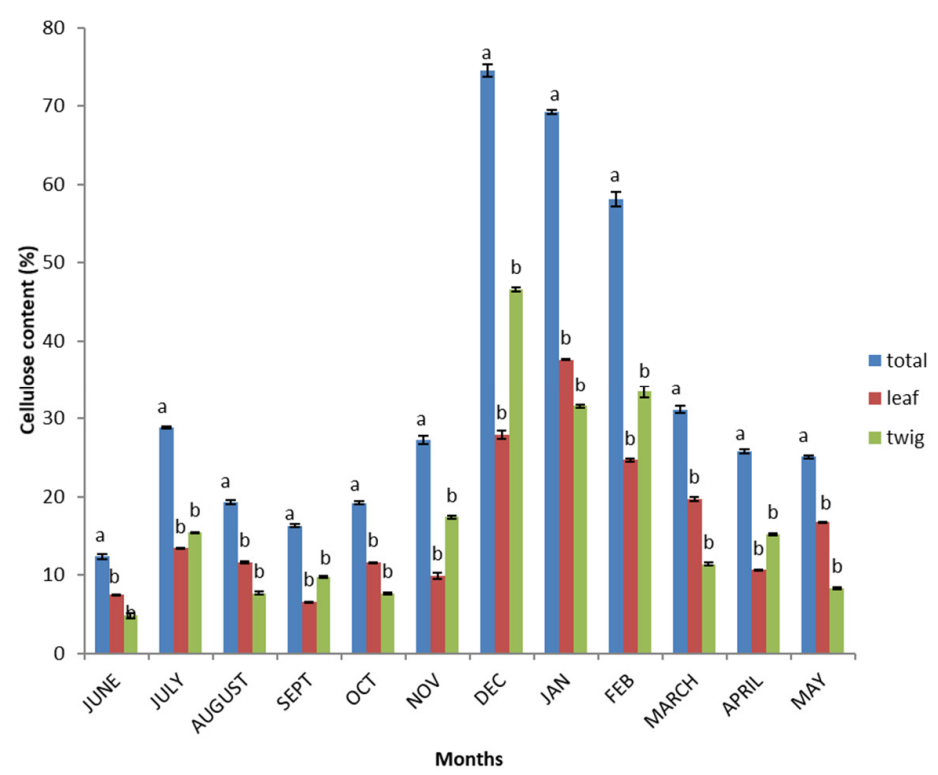

Figure 2a. Monthly cellulose content in the litter fall of bamboo stands in a regenerating forest, Ile-Ife. *Vertical bars of the same alphabet in a month are not significantly $(p>0.05)$ different using Duncan Multiple Range Test (DMRT).

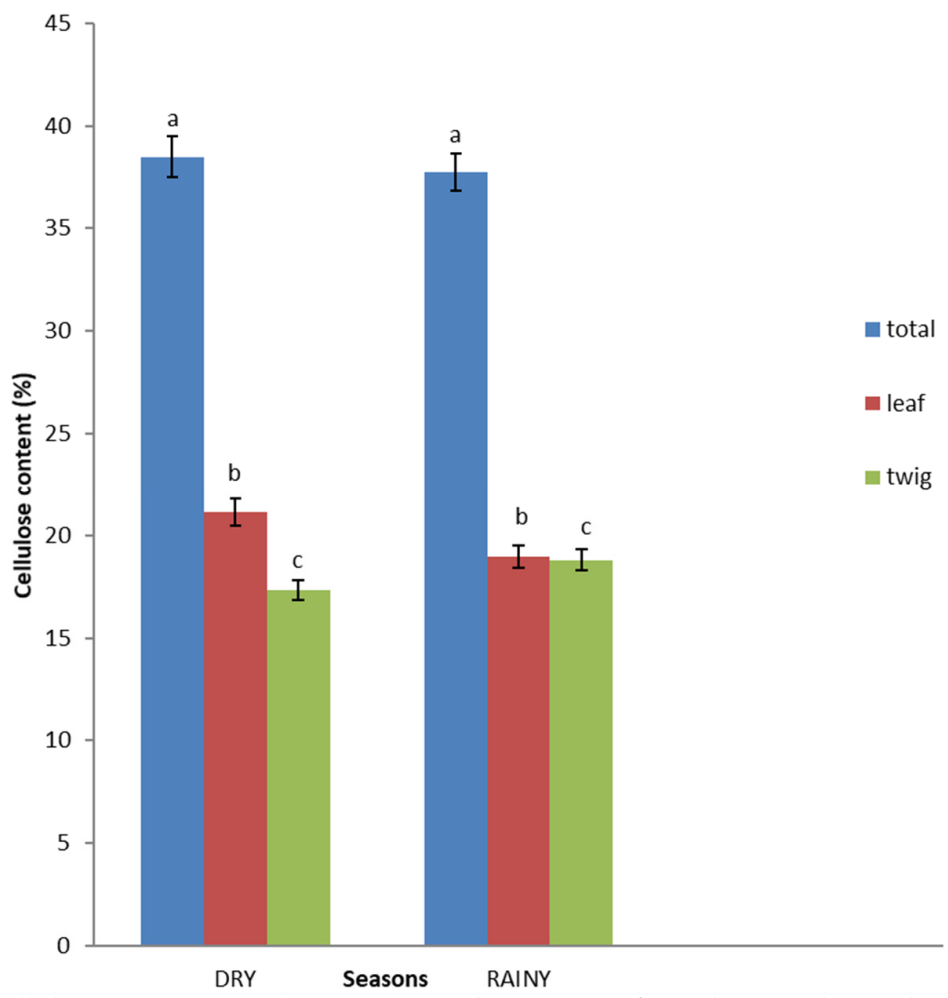

Figure 2b. Cellulose Content in the Litter Standing Crop of Bamboo at the Peak of Seasons in a regenerating forest, Ile-Ife

${ }^{*}$ Vertical bars of the same alphabet in a month are not significantly $(\mathrm{p}>0.05)$ different using Duncan Multiple Range Test (DMRT). 

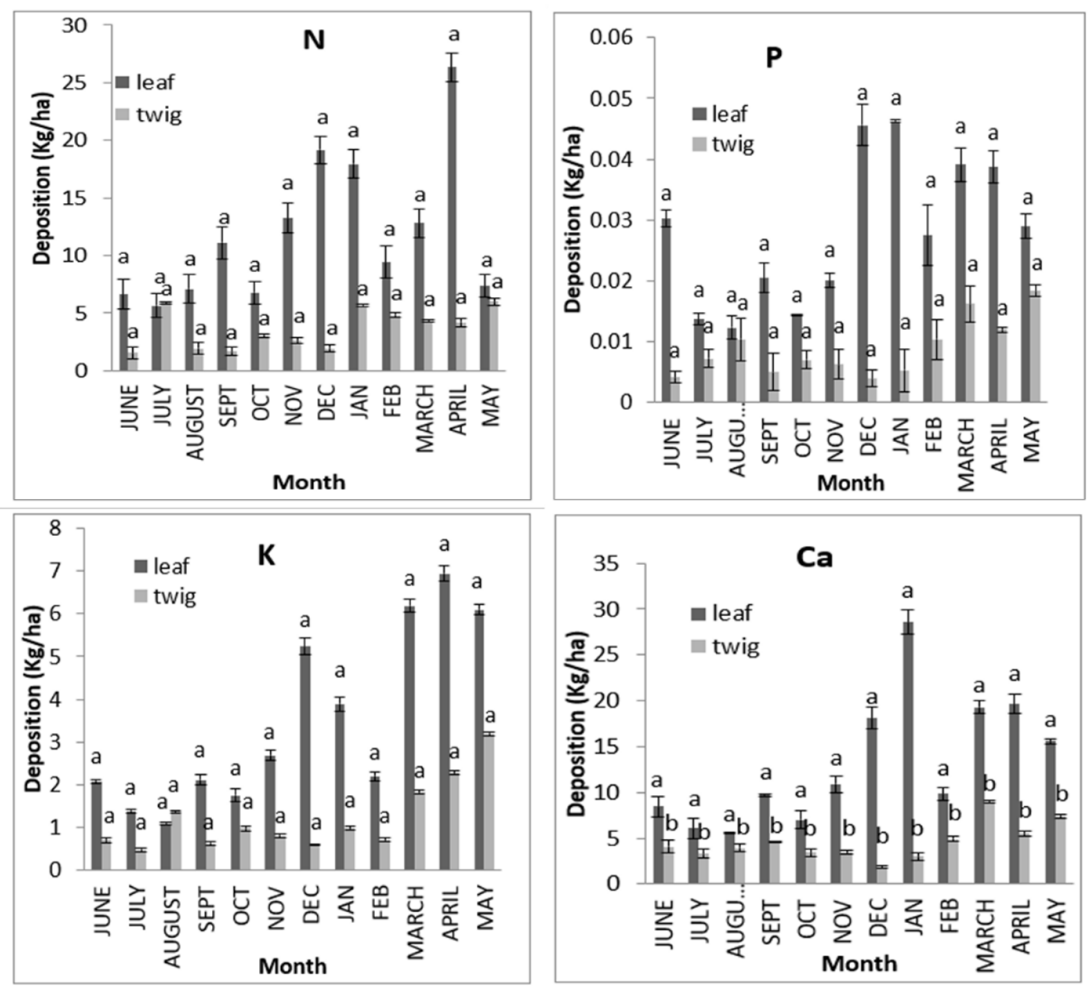

Figure 3a. Monthly nutrient deposition via litter fall in the bamboo stands in a Regenerating rainforest, Ile-Ife

*Vertical bars of the same alphabet in a month are not significantly $(\mathrm{P}>0.05)$ different using Duncan Multiple Range Test (DMRT).
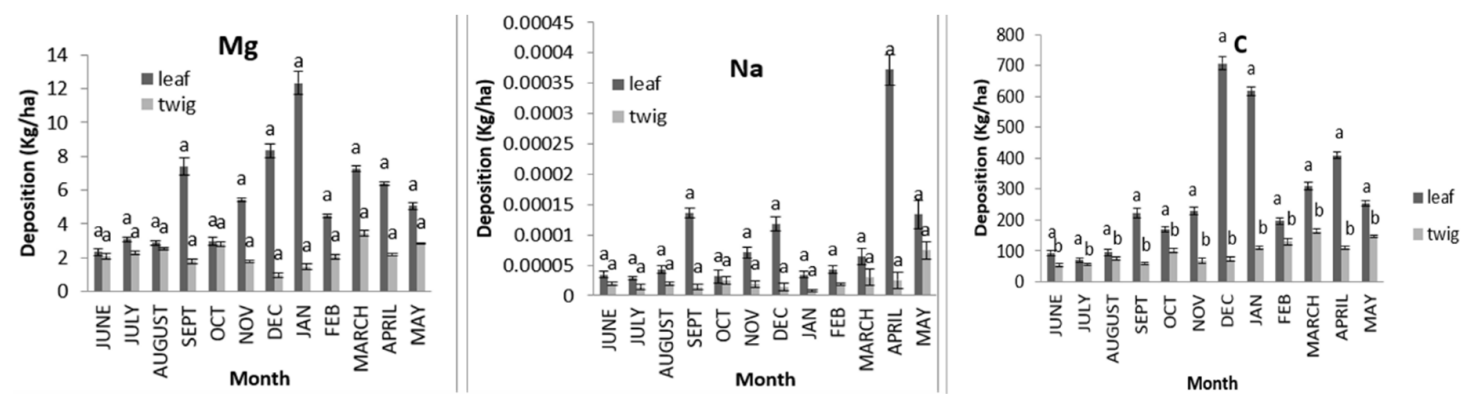

Figure 3b. Monthly nutrient deposition via litter fall in the bamboo stands in a Regenerating rainforest, Ile-Ife

${ }^{*}$ Vertical bars of the same alphabet in a month are not significantly $(\mathrm{P}>0.05$ different using Duncan Multiple Range Test (DMRT). 

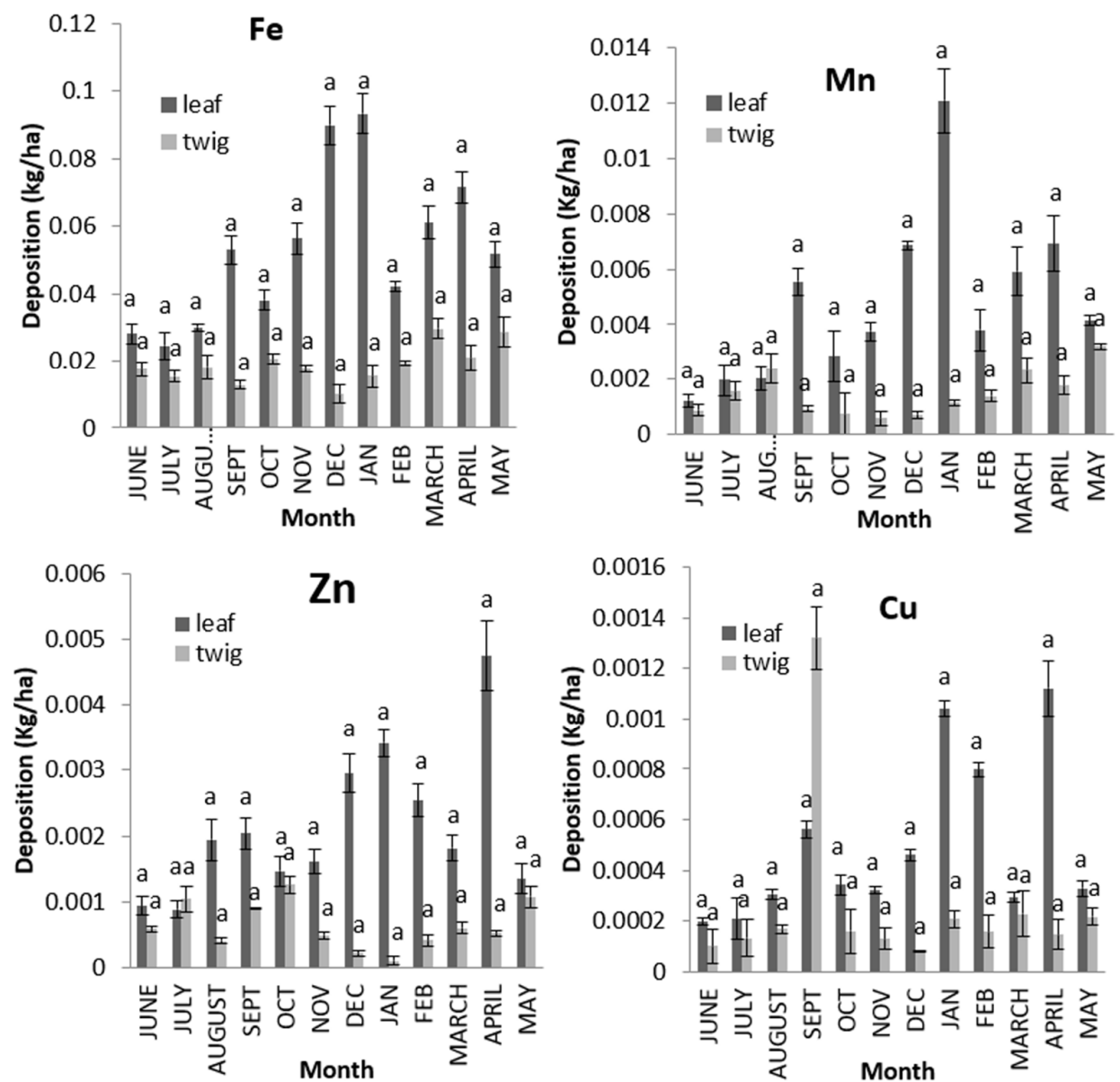

Figure 3c. Monthly nutrient deposition via litter fall in the bamboo stands in a Regenerating forest, Ile-Ife *Vertical bars of the same alphabet in a month are not significantly $(\mathrm{P}>0.05)$ different using Duncan Multiple Range Test (DMRT).

Table 1. Nutrient element deposition $\left(\mathrm{kg} \mathrm{ha}^{-1}\right)$ in the litter standing crop of the bamboo stands at the peak of seasons in a regenerating rainforest, Ile-Ife

\begin{tabular}{|c|c|c|c|c|}
\hline \multirow{3}{*}{ Parameters } & \multicolumn{4}{|c|}{ Season } \\
\hline & \multicolumn{2}{|c|}{ Dry } & \multicolumn{2}{|c|}{ Rainy } \\
\hline & Leaf & Twig & Leaf & Twig \\
\hline $\mathrm{Ca}$ & $9.88 \pm 0.16^{\mathrm{a}}$ & $4.93 \pm 0.24^{\mathrm{b}}$ & $1.79 \pm 0.07^{\mathrm{c}}$ & $1.62 \pm 0.03^{\mathrm{d}}$ \\
\hline $\mathrm{Mg}$ & $2.21 \pm 0.04^{a}$ & $0.85 \pm 0.07^{\mathrm{b}}$ & $0.72 \pm 0.07^{\mathrm{c}}$ & $0.46 \pm 0.03^{\mathrm{d}}$ \\
\hline $\mathrm{K}$ & $3.39 \pm 0.03^{a}$ & $2.04 \pm 0.01^{\mathrm{d}}$ & $2.30 \pm 0.08^{\mathrm{b}}$ & $1.22 \pm 0.08^{\mathrm{c}}$ \\
\hline $\mathrm{N}$ & $9.00 \pm 0.75^{\mathrm{a}}$ & $3.06 \pm 0.89^{c}$ & $1.59 \pm 0.69^{\mathrm{d}}$ & $3.30 \pm 0.90^{\mathrm{b}}$ \\
\hline $\mathrm{C}$ & $15.48 \pm 2.30^{\mathrm{a}}$ & $8.05 \pm 0.93^{c}$ & $8.45 \pm 0.18^{b}$ & $5.45 \pm 0.74^{\mathrm{d}}$ \\
\hline $\mathrm{Na}$ & $0.0000396 \pm 3 E-5^{a}$ & $0.000023 \pm 0.000001^{\mathrm{d}}$ & $0.0000302 \pm 4 \mathrm{E}-5^{\mathrm{c}}$ & $0.0000317 \pm 0.000003^{b}$ \\
\hline $\mathrm{P}$ & $0.0032 \pm 0.0003^{a}$ & $0.0024 \pm 0.0002^{\mathrm{b}}$ & $0.0014 \pm 0.00027^{c}$ & $0.00076 \pm 0.00003^{\mathrm{d}}$ \\
\hline $\mathrm{Mn}$ & $0.0011 \pm 0.00026^{\mathrm{a}}$ & $0.00069 \pm 0.000014^{\mathrm{b}}$ & $0.00054 \pm 0.03^{c}$ & $0.00047 \pm 0.00005^{\mathrm{d}}$ \\
\hline $\mathrm{Fe}$ & $0.034 \pm 0.88^{\mathrm{a}}$ & $0.015 \pm 0.66^{\mathrm{b}}$ & $0.015 \pm 0.08^{\mathrm{b}}$ & $0.0097 \pm 0.00078^{c}$ \\
\hline $\mathrm{Zn}$ & $0.0012 \pm 0.0007^{\mathrm{a}}$ & $0.00037 \pm 0.00001^{\mathrm{b}}$ & $0.00037 \pm 0.00002^{\mathrm{b}}$ & $0.00035 \pm 0.0004^{\mathrm{c}}$ \\
\hline $\mathrm{Cu}$ & $0.0031 \pm 0.0001^{b}$ & $0.00034 \pm 0.00009^{a}$ & $0.00017 \pm 0.00005^{c}$ & $0.00010 \pm 0.0004^{\mathrm{d}}$ \\
\hline
\end{tabular}

(DMRT). 
Comparison in nutrients deposition through litter fall in the bamboo stands with other areas in the secondary rainforest over the years

The nutrients deposition $\left(\mathrm{kg} \mathrm{ha}^{-1} \mathrm{yr}^{-1}\right)$ in the bamboo stands was compared with the 1990 and 2013 studies (areas where the stands are not located). The depositions of $\mathrm{Ca}, \mathrm{Mg}, \mathrm{Cu}$ and $\mathrm{N}$ were higher in the bamboo stands but lower in $\mathrm{Na}, \mathrm{Mn}$ and $\mathrm{Zn}$ deposition in 1990 and 2013 studies (Comparison of nutrients deposition $\left(\mathrm{Kg} \mathrm{ha}^{-1} \mathrm{yr}^{-1}\right)$ in the bamboo stands with other areas in the regenerating rainforest, Ile-Ife, Nigeria). The deposition of $\mathrm{K}$ in the bamboo stands was higher compared to study carried out previously in 1990 but lower than that of 2013 and vice versa in Fe (Table 2). Deposition of $\mathrm{P}$ and $\mathrm{Zn}$ in the bamboo stands was lower than the 1990 and 2013 studies (Table 2). The deposition of organic $\mathrm{C}$ in the bamboo stands was higher than the 2013 study (Table 2).

Table 2. Comparison of Nutrients Deposition $\left(\mathrm{Kg} \mathrm{ha}^{-1} \mathrm{yr}^{-1}\right)$ in the bamboo stands with other area in the regenerating rainforest, Ile-Ife, Nigeria

\begin{tabular}{|c|c|c|c|}
\hline \multirow{2}{*}{ Elements } & \multicolumn{3}{|c|}{ Year of study } \\
\cline { 2 - 4 } & 1990 & 2013 & 2017 \\
Forest & Forest & Bamboo Stands \\
\hline $\mathrm{Ca}$ & 96.89 & 132.18 & 213.19 \\
\hline $\mathrm{Mg}$ & 15.38 & 30.69 & 94.29 \\
\hline $\mathrm{K}$ & 44.58 & 83.54 & 56.23 \\
\hline $\mathrm{N}$ & 65.58 & 31.63 & 186.98 \\
\hline $\mathrm{C}$ & $\mathrm{ND}$ & 3232.94 & 4529.462 \\
\hline $\mathrm{P}$ & 3.81 & 0.5 & 0.44 \\
\hline $\mathrm{Mn}$ & 0.84 & 0.32 & 0.07 \\
\hline $\mathrm{Fe}$ & 5.08 & 0.55 & 0.87 \\
\hline $\mathrm{Zn}$ & 0.08 & 0.106 & 0.009 \\
\hline $\mathrm{Cu}$ & 0.02 & 0.0416 & 0.00138 \\
\hline $\mathrm{Na}$ & 3.37 & 0.0267 & \\
\hline
\end{tabular}

${ }^{*}$ ND- Not determined.

Source of 1990 data is from Muoghalu et al. (1993-2003) and from Afolabi (2014).

\section{Discussion}

The variation in lignin content observed compared to other studies (Liese, 1992; Scurlock et al., 2000 Dora, 2008; Ekebafe et al., 2010) could be attributed to the higher age in the stands. The result in this study agrees with findings of Peng et al. (2012), who reported that the amount of lignin content in the bamboo stands varies slightly depending on the age. It was observed that the litter production was relatively high during December which coincided with when the lignin content was at its peak. This agrees with assertions made by Vitousek et al. (1994) and Shaw and Hart (2001) that litter production and nutrient release are controlled by a wide variety of chemical properties of the litter, which includes lignin concentration or lignin to $\mathrm{N}$ ratio. The cellulose content obtained from this study lies within 50-70\% reported for bamboo species by Liese (1992); Scurlock et al. (2000); Dora (2008); Ekebafe et al. (2010). The cellulose content in the peak of dry seasons (38.47\%) was slightly higher than in the peak of rainy seasons $(37.76 \%)$.

The mean monthly nutrient deposition values of $\mathrm{C}, \mathrm{N}, \mathrm{P}, \mathrm{K}, \mathrm{Ca}$ and $\mathrm{Mg}$ compares favourably with reported values on bamboo species (Scurlock et al., 2000; Embaye et al., 2005; Nath and Das, 2012). Litter fall from the forest to the floor is normally considered as the main way for nutrient return to the soil (Borisade and Odiwe, 2018). The Nutrients deposition across the peak of seasons indicated that the $\mathrm{N}$ content compares favourably with $16.06-22.68 \mathrm{Kg} \mathrm{ha}^{-1}$ reported by Nath and Das (2012) but lower than $29.3 \mathrm{Kg} \mathrm{ha}^{-1}$ reported by Tripathi and Singh (1994). The P and K content were relatively lower than 1.05 and $1.74-2.65 \mathrm{Kg} \mathrm{ha}{ }^{-1}$; 
14.60 and 7.49-11.92 respectively reported by Tripathi and Singh (1994); Nath and Das (2012). The higher carbon deposition compared to other elements in this study may be attributed to the higher carbon concentrations in the litter fall and high carbon sequestration activity associated with bamboo and lower nutrient deposition of $\mathrm{Na}$ may be probably due to low concentration in the litter fall material. The higher nutrients deposition at the peak of dry season than at the peak of rainy seasons may be due to lower concentrations which influences the nutrient input in the litter of the bamboo stands during the rainy season; the growing season, when the nutrient dilution through growth is at its peak (Embaye et al., 2005; Borisade and Odiwe, 2018).

The higher depositions of $\mathrm{Ca}, \mathrm{Mg}, \mathrm{Cu}$ and $\mathrm{N}$ in the bamboo stands compared to 1990 and 2013 was probably due to higher concentration of nutrients in the litter fall, nature of the species and age. The lower deposition of $\mathrm{Na}, \mathrm{P}, \mathrm{Mn}$ and $\mathrm{Zn}$ in the bamboo stands compared to 1990 and 2013 may be attributed to lower concentration of the nutrients and nature of the species. The higher deposition of $\mathrm{K}$ in the bamboo stands than that of 1990 may be attributed to the older age in the stands compared to the 1990 study. The lower deposition of K compared to 2013 study may be probably due to the fact that it is more readily leached in the stands than other areas studied. Borisade and Odiwe (2018) reported potassium to be readily leachable in Bambusa vulgaris stands due to continuous harvesting. The high carbon deposition in the stands compared to other areas studied in 2013 may be attributed to high carbon sequestration ability of bamboo resulting in relatively higher nutrient deposition. This is consistent with assertion made by Anonymous (1997), Zhou et al. (2005), Borisade and Odiwe (2018) that the carbon sequestration ability of bamboo is likely to be second to none and if at all, only few.

\section{Conclusions}

There was significant monthly variation in the total lignin deposited among component of the litter fall with its peak in the month of December (dry month) and least in April (rainy month). There was no significant difference ( $p>0.05)$ between components of the litter fall and standing crop of litter in the cellulose.

The higher deposition of $\mathrm{C}, \mathrm{N}, \mathrm{Ca}, \mathrm{Mg}$ and $\mathrm{Cu}$ in the litters of the stands compared to previous studies which focused mainly on woody species in same secondary forest is an indication that the stands contributed significantly to the carbon sequestration, nutrient dynamics and regeneration status of the forest. Hence, the stands should be properly managed, for the functioning of the forest ecosystem.

\section{Acknowledgements}

I want to thank my colleague, Dr. Afolabi Akinjide and Prof. J.I. Muoghalu for granting me permission to use their data for comparison in the secondary forest where this research was conducted.

\section{Conflict of Interests}

The author declares that there are no conflicts of interest related to this article. 


\section{References}

Afolabi AM (2014). Changes in net precipitation, litter production and inorganic element input in a secondary rainforest, after 29 years of fire-induced succession. MSc thesis, Obafemi Awolowo University, Ile-Ife, Nigeria.

Allen SE, Grinshaw HM, Parkinson JA, Quarmby C (1974). Chemical analysis of ecological materials. Blackwell Scientific Publications, Oxford, England pp 551.

Anonymous (1997). Study on sustainable bamboo management. Final report, Luso Consult, 72- Hamburg, Germany.

Boateng AA, Weimer PJ, Jung HG, Lamb JF (2008). Response of thermochemical and biochemical conversion processes to lignin concentration in alfalfa stems. Energy and Fuels 22:2810-2815. https://doi.org/10.1021/ef800176x

Borisade TV, Odiwe AI (2018). Nutrient input in litters and soil of Bambusa vulgaris schrad.Exj.c.Wendl. stands in secondary Rainforest. Journal of Tropical Forest Science 30(2):195-206. https://doi.org/10.265251jtfs2018.30.2.195206

Cassida KA, Muir JP, Hussey MA, Read JC, Venuto BC, Ocumpaugh WR (2005). Biofuel component concentrations and yields of switchgrass in South Central U.S. environments. Crop Science 45:682-692

Das DK, Chaturvedi OP (2006). Bambusa bambos (L.) Voss plantation in eastern India: Culm recruitment, dry matter dynamics and carbon flux. Journal of Bamboo and Rattan 5:47-59.

Dora S (2008). Bamboo as a source of bioenergy feedstock in Ghana. MSc thesis. Kwame Nkrumah University of Science and Technology. Department of Wood Technology and Industrial Management, Ghana.

Ekebafe LO, Ekebafe MO, Akpa FAO, Erhuanga G, Etiobhio BW (2010). Graft copolymerization of acrylo-nitrile onto delignified native bamboo (Bambusa vulgaris) cellulosic and its utilization potential for heavy metal uptake from aqueous medium. Chemical Industry and Chemical Engineering Quarterly/CICEQ 17(2):133-140. https://doi.org/10.2298/ciceq101021063e

Embaye K, Weih M, Ledin S, Christersson L (2005). Biomass and nutrient distribution in a highland bamboo forest in southwest Ethiopia: implications for management. Forest Ecology and Management 204:159-169. https://doi.org/j.foreco.2004.07.074

Goering HK, Van soest PJ (1970). Forage fiber analysis (Apparatus, reagents, procedures and some applications). Agricultural Handbook, 379, Washington, DC.

Hunter IR, Junqui W (2002). Bamboo biomass. (Working paper No. 36). Beijing, People's Republic of China: International Network for Bamboo and Rattan (INBAR) 11:1-7.

Liese W (1992). The structure of bamboo in relation to its properties and utilisation. Proc: International Symposium on Industrial Use of Bamboo International Tropical Timber Organisation - Chinese Academy of Forestry.

Muoghalu JI, Akanni SO, Eretan OO (1993). Litterfall and nutrient dynamics in a Nigerian rainforest seven years after a ground fire. Journal of Vegetation Science 4:303-328. https://doi.org/10.2307/3235590

Nath AJ, Das AK (2012). Litter fall dynamics in village bamboo grove of Barak Valley, Assam. International Journal of Ecology and Environmental Sciences 38(1):1-8

Okubo K, Fujii T, Yamamoto Y (2004). Development of bamboo-based polymer composites and their mechanical properties. Composites 35(3):377-383. https://doi.org/10.1016/j.compositesa.2003.09.017

Peng H, Wang N, Hu ZR, Yu ZP, Liu YH, Zhang JS, Ruan R (2012). Physiochemical characterization of hemicellulose from bamboo (Phyllostachys pubescens Mazel) stem. Industrial Crops and Products 37(1):41-50. https://doi.org/10.1016/j.indcrop.2011.11.031

Scurlock JMO, Dayton DC, Hames B (2000) Bamboo: an overlooked biomass resource? Biomass and Bioenergy 19(4):229-244. https://doi.org/10.1016/S0961-9534(00)00038-6

Shanmughavel P, Peddappaiah RS, Muthukumar T (2001). Litter production and nutrient return in Bambusa bambos plantations. Journal of Sustainable Forestry 11(3):71-82. https://doi.org/10.1300/J091v11N03_04

Shaw MR, Harte J (2001). Response of nitrogen cycling to stimulated climate change: differential responses along a subalpine ecotone. Global Change Biology 7:193-210. https://doi.org/10.1046/j.1365-2486.2001.00390.x

Tel DA, Rao PV (1982). Automated analysis and semi- automated methods for soil and plant analysis. In: Manual series No. 7. International Institute of Tropical Agriculture, Ibadan, pp 39-45.

Tripathi SK, Singh KP (1994). Productivity and nutrient cycling in recently harvested mature bamboo savannas in the dry tropics. Journal of Applied Ecology 31:109-124. https://doi.org/10.2037/2404604

Uday DN, Matthews KC, Sujatha D, Mamatha BS, Anand N (2008). Development of bamboo mat moulded skin board for hollow core doors. IPIRTI Technical Report No. 108. 
Van Soest PJ, Robertson (1985). Analysis of forage and fibrous foods: a laboratory manual for animal science. Vol 613. Cornell University, Ithaca, New York, USA.

Vitousek PM (1984). Litterfall, nutrient cycling and nutrient limitation in tropical forests. Ecology 65:285-298. https://doi.org/10.2307/1939481

Zhou B, Fu M, Xie J, Yang X, Li Z (2005). Ecological functions of bamboo forests: Research and application. Journal of Forestry Research 16(2):143-147. https://doi.org/10.1007/BF02857909

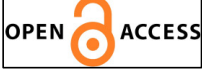

(c) (i)
The journal offers free, immediate, and unrestricted access to peer-reviewed research and scholarly work. Users are allowed to read, download, copy, distribute, print, search, or link to the full texts of the articles, or use them for any other lawful purpose, without asking prior permission from the publisher or the author.

License - Articles published in Notulae Scientia Biologicae are Open-Access, distributed under the terms and conditions of the Creative Commons Attribution (CC BY 4.0) License.

(c) Articles by the authors; SHST, Cluj-Napoca, Romania. The journal allows the author(s) to hold the copyright/to retain publishing rights without restriction. 